\title{
Festividades cívico-patrióticas na formação da juventude brasileira nas cidades fronteiriças de Porto União (SC) e União da Vitória (PR) em 1941
}

\author{
Civic-patriotic festivities in the formation of brazilian youth in the border cities \\ of Porto União (SC) and União da Vitória (PR) in 1941
}

\section{Festividades cívico-patrióticas en la formación de la juventud brasiliera en las ciudades fronterizas de Porto União (SC) y União da Vitória (PR) en 1941}

\author{
Márcia Marlene Stentzler ${ }^{2}$ \\ Marina Gabrielli Topolski Chelepa ${ }^{3}$
}

\begin{abstract}
Resumo: Neste artigo analisamos o papel de festividades e desfiles cívicos na formação da juventude nas cidades fronteiriças de União da Vitória (PR) e Porto União (SC), a partir do Decreto-Lei no 2072, de 8 de março de 1940, que institui e fixa bases para a educação cívica, moral e física para crianças e jovens matriculados em estabelecimentos de ensino. Para isso, utilizamos fotografias localizadas no Arquivo Público de Florianópolis e notícias publicadas pelo periódico "O Comércio", de Porto União (SC), revelando o entusiasmo com a formação da juventude e infância por ocasião da comemoração alusiva à Independência do Brasil e à Juventude Brasileira. A pesquisa é de cunho sócio-histórico e está vinculada ao Núcleo de Catalogação e Pesquisas em História da Educação (Nucathe), curso de Pedagogia da Unespar - União da Vitória (PR). Como base teórica, citamos Bencostta (2006; 2011); Hobsbawm (1990; 1998) e Horta (2012). Durante o Estado Novo, portanto, o culto aos símbolos pátrios durante sessões públicas tornou-se obrigatório para crianças e jovens estudantes de 7 a 18 anos, conformando uma cultura dentro de perspectivas ideológicas específicas do período ditatorial.
\end{abstract}

Palavras-chave: Desfiles. Festividades cívico-patrióticas. Juventude. Infância. Estado Novo.

\begin{abstract}
In this article we analyze the role of civic festivities and parades in the formation of youth in the border cities of União da Vitória (PR) and Porto União (SC), based on Decree-Law No. 2072, March 8, 1940, for civic, moral and physical education to children and young people enrolled in educational establishments. For this, we used photographs located in the Public Archive of Florianópolis and news published by the newspaper $O$ Comércio, from Porto União (SC), revealing the enthusiasm with the formation of youth and childhood on the occasion of the commemoration alluding to the Independence of Brazil and Juventude Brasileira movement. The research is of socio-historical nature, and is linked to the Nucleus of Cataloging and Research in History of Education (Nucathe), Unespar's Pedagogy course - in União da Vitória (PR). As a theoretical basis, we refer to Bencostta (2006; 2010); Hobsbawm (1990; 1998) and Horta (2012). During the Estado Novo, therefore, the cult of patriotic symbols during public sessions became obligatory to children and young students, from 7 to 18 years old, conforming a culture within the specific ideological perspectives of the dictatorial period.
\end{abstract}

Keywords: Parades. Civic-Patriotic Festivities. Youth. Childhood. Estado Novo.

Resumen: En este artículo analizamos papel de festividades y desfiles cívicos en la formación de la juventud, en las ciudades fronterizas de União da Vitória (PR) y Porto União (SC), a partir del Decreto-Ley $n^{o} 2072$ de 8 de marzo de 1940, que instituye y fija bases para la educación cívica, moral y física a los niños y jóvenes matriculados en centros de enseñanza. Utilizamos fotografías localizadas en el Archivo Público de Florianópolis y noticias publicadas por el periódico O Comercio, de Porto Unión (SC), revelando el entusiasmo con la formación de la juventud e infancia con motivo de la conmemoración alusiva a la Independencia del Brasil a la Juventud Brasileña. La investigación es de cuño socio histórico y está vinculada

\footnotetext{
${ }^{1}$ Submetido em: 20 out. 2018 - Aceito em: 13 fev. 2019 - Publicado em: 29 dez. 2019

${ }^{2}$ Universidade Estadual do Paraná (UNESPAR) - E-mail: mmstentzler@ gmail.com

${ }^{3}$ Universidade Estadual do Paraná (UNESPAR) - E-mail: marinagabriellit@gmail.com
} 
al Núcleo de Catalogación e Investigaciones en Historia de la Educación (Nucathe), curso de Pedagogía de la Unespar, União da Victoria (PR). Como base teórica, citamos Bencostta (2006; 2011); Hobsbawm (1990; 1998) y Horta (2012). Durante el Estado Nuevo el culto a los símbolos patrios durante las sesiones públicas se volvió obligatorio para niños y jóvenes estudiantes de 7 a 18 años, conformando una cultura dentro de perspectivas ideológicas específicas del período dictatorial.

Palabras clave: Desfiles. Festividades Cívico-Patrióticas. Juventud. Infancia. Estado Nuevo.

\section{Introdução}

Para a República, a escola primária tornou-se a instituição de referência na difusão de um corpo de conhecimento reconhecido e normatizado pelo Estado, objetivando, de acordo com Lopes (2012, p. xi), uma "sociedade feita aos moldes das necessidades e interesses" de uma elite dominante. Somado ao conjunto de conteúdos específicos das diferentes disciplinas, a formação do cidadão com espírito patriótico fez parte de programas educacionais, com normativas específicas do Estado para a organização da instrução pública e o culto ao civismo. A formação escolar adquire ênfases específicas por meio dos currículos e ensino de língua estrangeira nas escolas nas décadas de 1910 e 1920, de acordo com Stentzler (2015). Contudo, foi na década de 1930 e 1940, com o denominado Estado Novo, que o culto patriótico assume centralidade na formação da juventude e infância brasileira.

$\mathrm{Na}$ ditadura de Vargas, exaltava-se a formação cívica, a cultura política do nacionalismo, o culto ao corpo e à disciplina, em nome da ordem e progresso nacional (COSTA, 2009), alicerçando também o processo de escolarização e a formação de professores (STENTZLER, 2018). O uso de elementos simbólicos, associados à formação da juventude, objetivava despertar um "sentimento de fidelidade para com o Estado [...] por meio de um aparato ideológico eficiente e de políticas nacionalizantes", enaltecendo o potencial da juventude na construção da nação (HOCHE, 2015, p. 16).

A escola passa a ser um "aparelho ideológico a serviço do Estado" e o sistema educacional é utilizado para "inculcar na infância e na juventude o espírito do novo regime" (HORTA, 2012, p. 160). A bandeira e o hino nacional "tradicionalmente são os símbolos nacionais mais evidentes" (CARVALHO, 1990, p. 109) nas solenidades cívicas e nas escolas. Eles eram utilizados com o intuito de mobilizar sentimentos e atitudes em prol da constituição de uma "estrutura de personalidade" a compor uma "identidade coletiva [...] uma alma coletiva" nacional (LEITE et al., 2018, p. 2065) e a educação era considerada o meio para corrigir distorções sociais, pela força homogeneizadora a ela atribuída (SAVIANI, 2012).

Pesquisas realizadas junto ao Arquivo Público de Florianópolis e ao arquivo do jornal O Comércio (1941a; 1941b) em Porto União, Santa Catarina, permitiram o acesso aos documentos e registros da imprensa local. Essas fontes são portadoras de representações acerca da educação e da pátria, da juventude e infância. O papel das representações na conformação socioeducacional pode ser compreendido com base em Chartier (1990), para quem as imagens e o contexto em que foram produzidas, assim como os discursos a elas 
associados, ficaram "determinados pelos discursos dos grupos sociais que as forjam" (PAULINO, 2018, p. 3).

Nesse sentido, as três fotografias, da mesma comemoração realizada nos dias 5 e 7 de setembro de 1941, localizadas no Arquivo Público de Florianópolis, revelam intencionalidades e expectativas de um grupo de pessoas influentes em relação à formação da juventude e o seu papel no futuro da nação e das duas cidades localizadas no interior dos estados do Paraná e de Santa Catarina. Elas atestam, também, a permeabilidade da política educacional do governo Vargas efetivada no período ditatorial do Estado Novo. Esses documentos são fragmentos da memória daquele período, quando o culto ao nacionalismo, ao civismo e ao pertencimento territorial aos estados do Paraná ou de Santa Catarina se fundiam na medida em que se idealizava o fortalecimento do sentimento de amor ao Brasil.

Nesse norte, objetivamos compreender o papel das festividades e desfiles cívicos na formação da juventude nas cidades fronteiriças de União da Vitória (PR) e Porto União (SC), após a publicação do Decreto-Lei n ${ }^{\circ}$ 2072, de 8 de março de 1940 (BRASIL, 1940), que instituiu e fixou bases para a educação cívica, moral e física para crianças e jovens. Tendo como base a perspectiva sócio-histórica, dialogamos com autores da área, consultamos a legislação específica, utilizamos imagens e notícias que permitem conhecer aspectos da formação da infância e juventude. O desfile cívico realizado pela avenida principal da cidade e as demais comemorações envolvendo estudantes das escolas e comunidade foram o ponto máximo da solenidade da Semana da Pátria em 1941, como ocorria em outras escolas de Santa Catarina que "alimentavam em suas tarefas pedagógicas os símbolos e imagens favoráveis ao regime”, conforme Santos (2012, p. 158).

A Organização Nacional da Juventude foi instituída por Getúlio Vargas, pelo DecretoLei ${ }^{\circ}$ 2072, de 8 de março de 1940 (BRASIL, 1940), a exemplo do que já ocorria em outros países, como Portugal (HOCHE, 2015; HORTA, 2012). A criação dessa entidade estava diretamente ligada aos interesses de Vargas na formação da consciência patriótica do jovem brasileiro com a educação cívica, moral e física, formando a mocidade para cumprir seus deveres com a pátria.

No ano de 1941 houve ênfase nos festejos, cuidadosamente organizados com oradores que exaltavam a Pátria, apresentações cívicas, competições esportivas, desfiles, vocalização de hinos e canções patrióticas, entre outros, segundo foi registrado em notícias divulgadas pelo jornal O Comércio (1941a; 1941b). O mesmo veículo de comunicação enalteceu a participação da igreja católica, de escolas públicas e privadas, revestindo de "grande brilho" as comemorações da "Juventude Brasileira e a nossa Independência Política", indicando a inter-relação que se estabelecia entre Igreja e Estado. As comemorações cívicas alcançavam as ruas da cidade e as representações sobre o papel da escola na formação da juventude eram disseminadas pela imprensa local.

As imagens e notícias trazem vestígios do passado, logo necessitam ser analisadas como um produto histórico datado e marcado por relações de poder (LE GOFF, 2003; HOBSBAWM, 1998). Respeitadas as especificidades da pesquisa, Borges (2003, p. 73) evidencia que as imagens fotográficas fazem parte do conjunto de "documentos que informam sobre a cultura material de um determinado período histórico [...] como uma forma 
simbólica que atribui significados às representações e ao imaginário social". As fotografias fornecem elementos para a compreensão do presente como parte de um processo sóciohistórico circunscrito no tempo/espaço da região que já havia sido disputada entre os estados do Paraná e Santa Catarina.

A pesquisa em história se alimenta à medida que fontes são preservadas e disponibilizadas para pesquisa, pois para Farge (2009, p. 31), um arquivo "nasce da desordem, por menor que seja; [e] arranca da obscuridade longa lista" de documentos que foram preservados por diferentes razões, em diferentes locais. $\mathrm{O}$ acervo histórico oportuniza ao pesquisador, sempre de forma incompleta e fragmentada, estudar e compreender o passado revelado por documentos e memórias que foram preservadas até os dias atuais, trazendo aspectos do passado político e educacional da região sul do Paraná e norte de Santa Catarina.

\section{Escolarização na região da Guerra do Contestado}

A cidade de Porto União da Vitória originou-se de uma vila que inicialmente pertencia à Freguesia de Palmas, município de Guarapuava (PR). A localidade era caminho de tropeiros devido ao vau (uma passagem rasa no Rio Iguaçu) que possibilitava a travessia das tropas vindas do Rio Grande do Sul rumo ao Estado de São Paulo, cidade de Sorocaba (SP). No final do século XIX, a pequena vila banhada pelo rio Iguaçu contava com internato para meninos e algumas escolas denominadas "promiscoas" (onde estudavam meninos e meninas). Em 1904, a primeira normalista chegava à cidade, a Professora Amasília Pinto de Araújo, formada na Escola Normal de Curitiba (GASPARI, 2011; STENTZLER, 2015).

No ano de 1906, a ferrovia alcançava a cidade representando o progresso. Os trilhos ligavam a cidade a São Paulo, levando as riquezas em seus vagões. Os trilhos se estenderam pelo território catarinense alcançando o Rio Grande do Sul entre 1907 e 1910. Com a construção concluída, agravou-se a tensão social na região, já que inúmeros trabalhadores ficaram desempregados e se juntaram a sertanejos que foram expulsos das terras onde viviam devido à ferrovia. Os Estados do Paraná e Santa Catarina disputavam a área territorial conhecida como Contestado. Somados, esses fatores oportunizaram o início da Guerra do Contestado que assolou a região pelo menos entre 1912 e 1916, envolvendo sertanejos, forças governamentais e civis (GALLO, 1999; MACHADO, 2004; TONON, 2010; STENTZLER, 2015).

Um dos desdobramentos ao final da guerra foi a assinatura do Acordo de Limites, dividindo a cidade de Porto União da Vitória (PR). De um lado dos trilhos o território ficou sob o domínio paranaense e do outro, catarinense. As cidades de União da Vitória (PR) e Porto União (SC) nasceram do único conjunto urbano, às margens do Rio Iguaçu, cujas principais riquezas eram de origem natural, como a erva-mate e a madeira, transportadas pelos vapores e, posteriormente, pelos trens.

As crianças e jovens das duas cidades frequentavam grupos escolares, escolas étnicas, como, por exemplo, a escola alemã (IHLENFELD, 2011) e escolas confessionais vinculadas à igreja católica. As jovens da cidade e região, cujos pais tinham poder aquisitivo, estudavam 
na Escola Normal Santos Anjos. Entre os principais estabelecimentos de ensino, no lado catarinense dos trilhos, elencamos: Escolas Reunidas de Porto União, criadas em 1918; o Grupo Escolar Balduíno Cardoso, criado em 1927 a partir das Escolas Reunidas e a Escola Complementar anexa, criada em 1928. Entre as escolas privadas, os colégios confessionais católicos: Santos Anjos, fundado em 1917 e Ginásio São José, em 1932. No lado paranaense funcionava a Casa Escolar Professor Serapião desde 1913, remodelada como Grupo Escolar em 1919 (KLEIN; STENTZLER, 2018). As escolas étnicas existiram até 1938, quando foi publicada a lei da nacionalização.

Nos municípios de União da Vitória (PR) e Porto União (SC) as escolas multisseriadas foram os principais locais para as crianças alcançarem a instrução por muitos anos. Essas escolas, localizadas nas cidades ou áreas rurais dos municípios, seguiam orientações e normas específicas dos respectivos estados, inclusive para as festividades escolares que eram realizadas conjuntamente com estudantes e comunidade, formando um "ambiente propício para difundir o sentimento patriótico entre os educandos e a população em geral” (STENTZLER, 2015, p. 122). Essas comemorações também integravam as populações das duas cidades, particularmente após 1935, com festividades conjuntas unindo escolares, autoridades e comunidade dos municípios fronteiriços.

As festividades escolares, consideradas as especificidades da pesquisa, podem ser consideradas "[um] fato social coletivo e carrega consigo um conjunto de significados que lhe são atribuídos conforme a história e a tradição em que foi gestada" (BENCOSTTA, 2011, p. 251). Os festejos cívicos eram marcados por forte impacto simbólico nacionalista, difundindo valores e comportamentos que eram parte da formação do novo cidadão brasileiro no governo ditatorial de Vargas. Por meio dos desfiles, a infância e a juventude brasileira demonstravam conhecimento cívico, difundindo laços de pertencimento ao Brasil e amor à Pátria.

\section{Juventude brasileira e escolarização}

A instituição nacional denominada Juventude Brasileira foi criada durante o Estado Novo pelo Presidente Getúlio Vargas objetivando a formação cívica, moral e física de crianças e jovens brasileiros, em prol do engrandecimento da pátria. Instituída pelo DecretoLei n $^{\circ}$ 2072, de 8 de março de 1940 (BRASIL, 1940), a exaltação à formação da juventude sob a égide de princípios nacionalistas, fez parte dos projetos da elite dirigente. Em cada cidade deveria existir centros cívicos escolares ou extraescolares. Os jovens seriam preparados para se "tornarem cidadãos aptos, física e moralmente, prontos para uma vida de doação à Nação à quem pertenciam e de perpetuação ao regime que os formara" (HOCHE, 2015, p. 66).

De acordo com Leite et al. (2018, p. 2017), a identidade nacional, entendida como um constructo, efetiva-se proporcionalmente à adesão dos indivíduos a "crenças patrióticas e nacionalistas" por meio de um movimento "ideológico que visa a autonomia, a unidade e a identidade de uma população, considerada como uma nação real ou potencial" (LEITE et al., 
2018, p. 2065). O sentimento de responsabilidade e compromisso deveria ser despertado desde a formação na escola, pela educação cívica, ressaltando a "confiança no próprio esforço, o hábito da disciplina, o gosto da iniciativa, a perseverança no trabalho e a mais alta dignidade em todas as ações e circunstâncias" (BRASIL, 1940, s.p.).

Os jovens do sexo masculino seriam estimulados a se consagrar ao serviço militar, defendendo a pátria. As moças, por sua vez, teriam um papel fundamental nas atividades do lar, desenvolvendo o "gosto dos serviços domésticos, principalmente dos que se referem à criação e à educação dos filhos" (BRASIL, 1940, s.p.). Cuidados especiais com a educação do corpo também integravam a proposta e a educação física desenvolveria os "hábitos e as práticas higiênicas que tinham por finalidade a prevenção de toda a sorte de doenças, a conservação do bem-estar e o prolongamento da vida" (BRASIL, 1940, s.p.). Previa-se que escolas e professores assumissem responsabilidades com a educação da infância e juventude brasileira, juntamente com a família. O Art. $7^{\circ}$ do Decreto-Lei $\mathrm{n}^{\mathrm{o}} 2072$, de 8 de março de 1940 estabelecia:

A educação ministrada pela Juventude Brasileira será base e complemento da educação ministrada pela escola e prolongamento da educação ministrada pela família. Entre a Juventude Brasileira, a escola e a família, haverá continuado entendimento e estreitos vínculos de cooperação (BRASIL, 1940, s.p.).

Podemos compreender esse movimento com base em Costa (2009, p. 20), para quem "esses sujeitos, aos olhos das elites políticas e dos intelectuais que se debatiam com as contradições de seu tempo, eram depositários das esperanças e dos temores acerca da utopia da nação". A ideia de nação, nos moldes propostos, alicerçava-se na conformação de sentimentos e atitudes nacionalistas, entretecendo ações na escola e na família. Para Hobsbawm (1990, p. 52-53), a existência de um estado-nação exigia a adequação "ao progresso ou à evolução histórica avançada" e o nacionalismo alargava a "escala da operação humana na economia, na sociedade e na cultura", resultando na necessidade de respeito e subordinação dos povos a outros maiores.

Nas cidades, os Centros Cívicos seriam indutores de mudanças. Eles foram criados com a finalidade de formação cívica, moral e física dos jovens. A difusão de ideais nacionalizantes foi realizada com a participação da imprensa escrita e falada, noticiando eventos e enaltecendo o civismo, disseminando representações acerca desse ideário junto à população e às escolas. Conforme escreve Stentzler (2015), as comemorações dessa natureza, em que jovens declamavam poesias e realizavam discursos, eram acompanhadas pela comunidade, registradas e divulgadas pelos meios de comunicação como forma de enaltecer o trabalho dos professores e a função da escola na formação do cidadão brasileiro.

Os alunos, devidamente uniformizados, certamente se destacavam entre outras crianças e jovens, percorriam as ruas até sua escola para participar da solenidade cívica, um acontecimento social que também difundia entre os moradores das duas cidades a imagem da escola [...] (STENTZLER, 2015, p. 121).

No ano de 1941, a comemoração da Independência do Brasil envolveu autoridades civis, militares e eclesiásticas, professores, estudantes e comunidade das cidades fronteiriças. A notícia sobre a solenidade, divulgada pelo periódico local, ocupou a primeira página, enaltecendo a ideia da formação da juventude e amor à pátria, aproximando autoridades e população das cidades: os "dias 5 e 7 deste mês, [foram] datas consagradas, respectivamente, 
à Juventude Brasileira e à nossa Independência Política" (O COMÉRCIO, 14/9/1941a, p. 1). Os símbolos nacionais, em particular, a bandeira, era enaltecida, hasteada e conduzida por jovens em desfiles.

Os detalhes como o hasteamento da Bandeira no Ginásio São José, um colégio confessional, em Porto União, no dia 5 de setembro de 1941 e a fotografia (Figura 1) com os estudantes perfilados na avenida em frente à Igreja Católica de Porto União (SC) mostram o entusiasmo com o momento festivo. Eventuais dificuldades ou mesmo resistência de alunos, professores ou autoridades em participar do evento são omitidas, o que é uma marca de governos autoritários.

Figura 1. Desfile de escolares

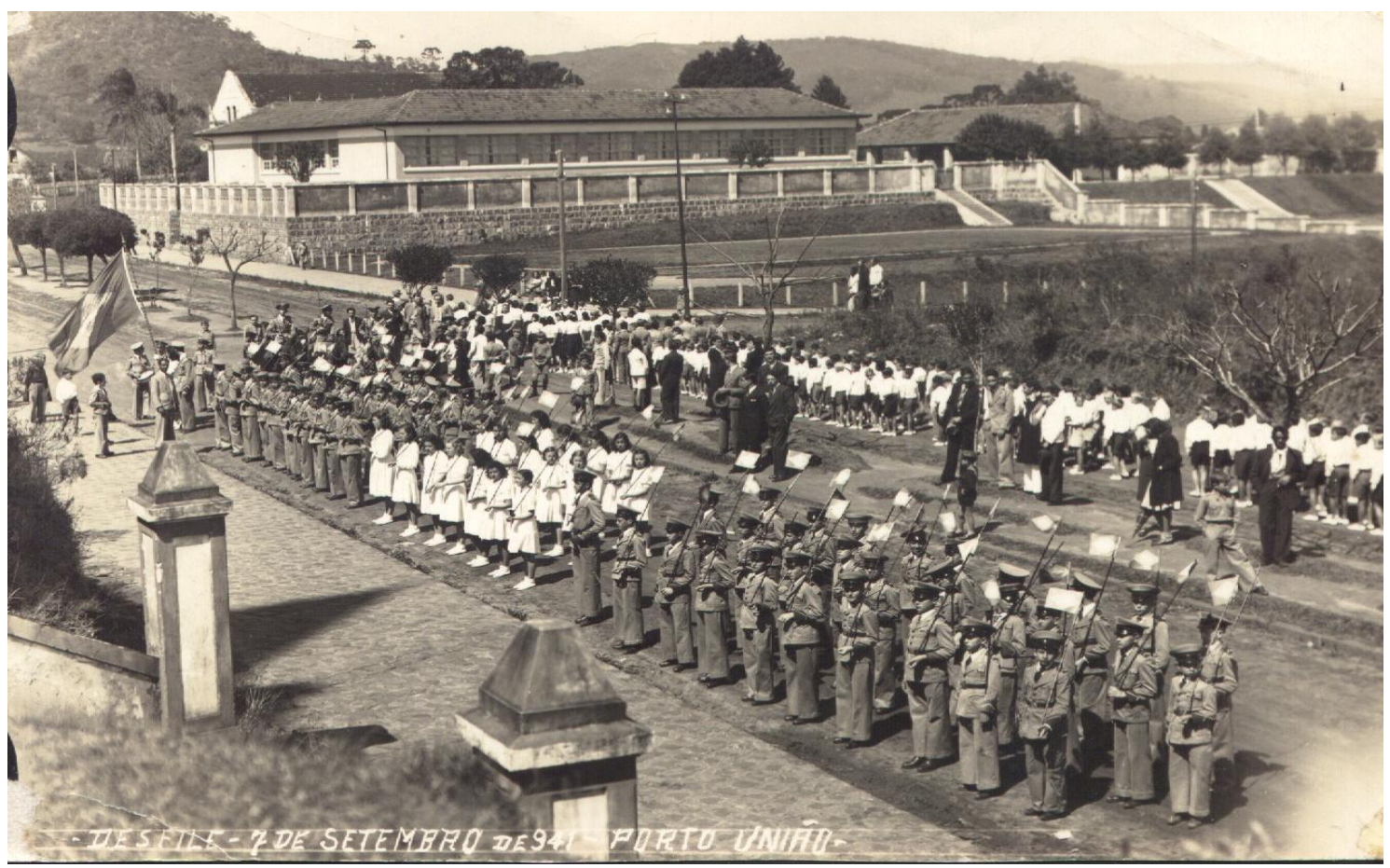

Fonte: Florianópolis: Arquivo Público, 1941.

Com a concentração de jovens e crianças para os festejos cívicos, essa imagem remete à ideia de disciplina e ordem. O Art. 18 do Decreto-Lei $n^{\circ}$ 2072, de 8 de março de 1940, estabelecia orientações que uniformizavam práticas como essa em toda a nação: as "formaturas a serem realizadas pela Juventude Brasileira consistirão em exercícios de concentração ou de deslocamentos, e visarão, pela criação da disciplina, do entusiasmo e da resistência, a fins educativos a um tempo de ordem cívica, moral e física" (BRASIL, 1940, s.p.), realizadas em público e com caráter solene. Devidamente uniformizados, os estudantes revelam a cultura socioeducacional em um tempo histórico pautado por ideais nacionalistas. Conforme Bobbio, Matteucci e Pasquino (1998, p. 804), e respeitadas as especificidades da pesquisa, movimentos dessa natureza "constituem uma etapa da evolução histórica" para a centralização do poder que exige lealdade por parte dos cidadãos, em prejuízo de lealdades para com as coletividades menores ou maiores do que a nação. Como era, por exemplo, na região de União da Vitória (PR) e Porto União (SC), onde havia grande número de migrantes 
de origem europeia. Eles eram forçados a aderir à língua portuguesa e cultuar os símbolos nacionais brasileiros.

À Juventude Brasileira delegou-se papel fundamental na ideologia de desenvolvimento nacional. A incumbência da sua administração era do governo federal, por meio de um Conselho presidido pelo "Presidente da República e constituído pelos Ministros de Estado da Educação, da Guerra e da Marinha", conforme estabelecia o Art. 23 (BRASIL, 1940). A legislação previa, ainda, que a pedagogia ativa fosse adotada no processo de formação, exemplificando no Art. 13 ações a realizar para atingir os objetivos com "processos de educação ativa, realizando formaturas, solenidades, demonstrações, trabalhos, exercícios, excursões, viagens e divertimentos" (BRASIL, 1940), respeitando o direcionamento didático-pedagógico, que seria o mesmo em escolas públicas ou privadas.

Contudo, a notícia publicada pelo O Comércio (14/9/1941a, p. 1) enaltece os estabelecimentos de ensino católicos da cidade e o seu papel na formação da juventude. A fotografia (Figura 1) documenta que os estudantes estavam em formatura, organizados na avenida em frente ao prédio do Ginásio São José e da Igreja Matriz de Porto União (SC), mas ambos os edifícios não aparecem na imagem que mostra o lindo prédio e a ampla área do Grupo Escolar Balduíno Cardoso, que foi entregue à população em 1938. Moças e rapazes estão em destaque no primeiro plano da fotografia, uniformizados e devidamente enfileirados com bandeirolas. Eles eram jovens estudantes do Ginásio São José e do Colégio Santos Anjos. No segundo plano, sobre o canteiro central da avenida, estão alguns adultos que, possivelmente, eram professores e professoras, bem como uma banda musical. Após eles, as crianças estavam uniformizadas, alunos dos grupos escolares das cidades vizinhas.

Após a concentração, os jovens participaram de uma "[...] imponente passeata, organizada com os escoteiros e escolares de União da Vitória, que percorreram, sob vibrantes aclamações, as principais ruas daquela e desta cidade", conforme noticiou O Comércio, Porto União (14/9/1941a, p. 1). A programação estendeu-se também no período noturno, quando "alunos do Ginásio São José, do Colégio Santos Anjos e do Grupo Escolar Prof. Balduíno Cardoso que, debaixo duma ordem que bem alto fala da disciplina que se mantém nos nossos estabelecimentos escolares, ofereceram à cidade momentos de intensa vibração cívica" realizando uma marcha com lanternas luminosas por ruas da cidade (O COMÉRCIO, 14/11/1941a, p. 1).

As "vistosas lanternas" empunhadas pelos estudantes que percorreram, à noite, as ruas da cidade trazem à tona a ideia da luz do conhecimento vencendo as trevas da ignorância, bem como o protagonismo da juventude brasileira na transformação da nação como parte do projeto civilizador para a sociedade brasileira. Ao considerar as especificidades da pesquisa, concordamos com Bencostta (2006, p. 300), para quem os "desfiles patrióticos reproduzem o cotidiano, uma ação com um tempo e um lugar determinado, implicando a concentração de afetos e emoções em torno de um assunto que é celebrado e comemorado e cujo principal produto é a simbolização de unidade dos participantes". Na região havia grande número de jovens e crianças que não falavam a língua portuguesa.

As duas escolas confessionais católicas existentes no município de Porto União (SC) ganham evidência por meio da imprensa, mas em particular o Ginásio São José é enaltecido 
pela "grandeza e a utilidade desse novel estabelecimento do ensino secundário" cuja direção estava a cargo de Frei Bertino, definido pelo jornalista como um "verdadeiro guardião" (O COMÉRCIO, 14/09/1941a, p. 1). Para Mélo Filho (2006), a Igreja Católica exerceu papel fundamental junto à sociedade civil para a existência do Estado Novo, apoiando-o. Recebeu em troca benefícios para reconquistar espaços educacionais perdidos anteriormente, fato que pode ser evidenciado por notícias publicadas pela imprensa local, dando relevância aos estabelecimentos católicos.

A pesquisa de Boto (2017, p. 14) aponta que as "ideias ganharam força em uma época" e se tornaram referenciais para mudanças na educação e sociedade. O espírito cívico e patriótico, inspirado na ideia de nacionalismo, deveria ser a base para uma identidade comum a brasileiros e estrangeiros, fossem eles catarinenses ou paranaenses. Os símbolos nacionais estavam presentes no cotidiano escolar. O texto do professor Estevam Juck, um respeitado educador local que se manifestou a favor das políticas governamentais, revela a crença no poder de transformação da educação pela formação da "juventude sadia e cheia de esperança", que por meio da educação construiria o Brasil do futuro (JUCK, 1941, p. 1). O professor, que também lecionava no Ginásio São José e, em 1930, havia exercido a função de diretor do Grupo Escolar Balduíno Cardoso e da Escola Complementar anexa, em Porto União (SC), reforçou os anseios da política governamental naquele momento:

O Brasil precisa de quem trabalha, precisa de operários cultos, de soldados instruídos, de cidadãos conscientes da sua responsabilidade [...] lembrai-vos sempre, que a força de uma nação e o valor de sua gente não está na extensão territorial nem na população - mas no preparo intelectual e moral de seus filhos [...] vós sois o futuro do Brasil, porque sois vós o Brasil de amanhã (JUCK, 1941, p. 1).

A educação das crianças e jovens, o "preparo intelectual e moral" era considerado uma condição básica para a formação da juventude e geração de uma nação forte, com "cidadãos conscientes de sua responsabilidade". Tamanho foi o entusiasmo da semana da Pátria que, para o editor do periódico, até a natureza "parecia estar também participando do júbilo nacional brasileiro [quando] puseram-se em ordem de marcha estudantes e atletas, que desfilando em torno da Bandeira, percorreram ruas de Porto União e União da Vitória" (O COMÉRCIO, 14/09/1941b, p. 1). Isso porque a formação da mente e o cuidado com o corpo estavam indissociados.

Com o apoio da Igreja Católica, a missa campal iniciou as atividades alusivas ao dia da Independência, celebrada pelo vigário, reunindo "representantes da imprensa, do comércio, das indústrias, das associações religiosas, recreativas e esportivas, escolares e grande número de fiéis" (O COMÉRCIO, 14/09/1941b, p. 1). A fotografia (Figura 2) registra a solenidade de hasteamento da Bandeira Nacional, realizado após a missa campal, com a presença de pessoas da comunidade e de estudantes uniformizados. 
Figura 2. Solenidade cívica na Praça Hercílio Luz

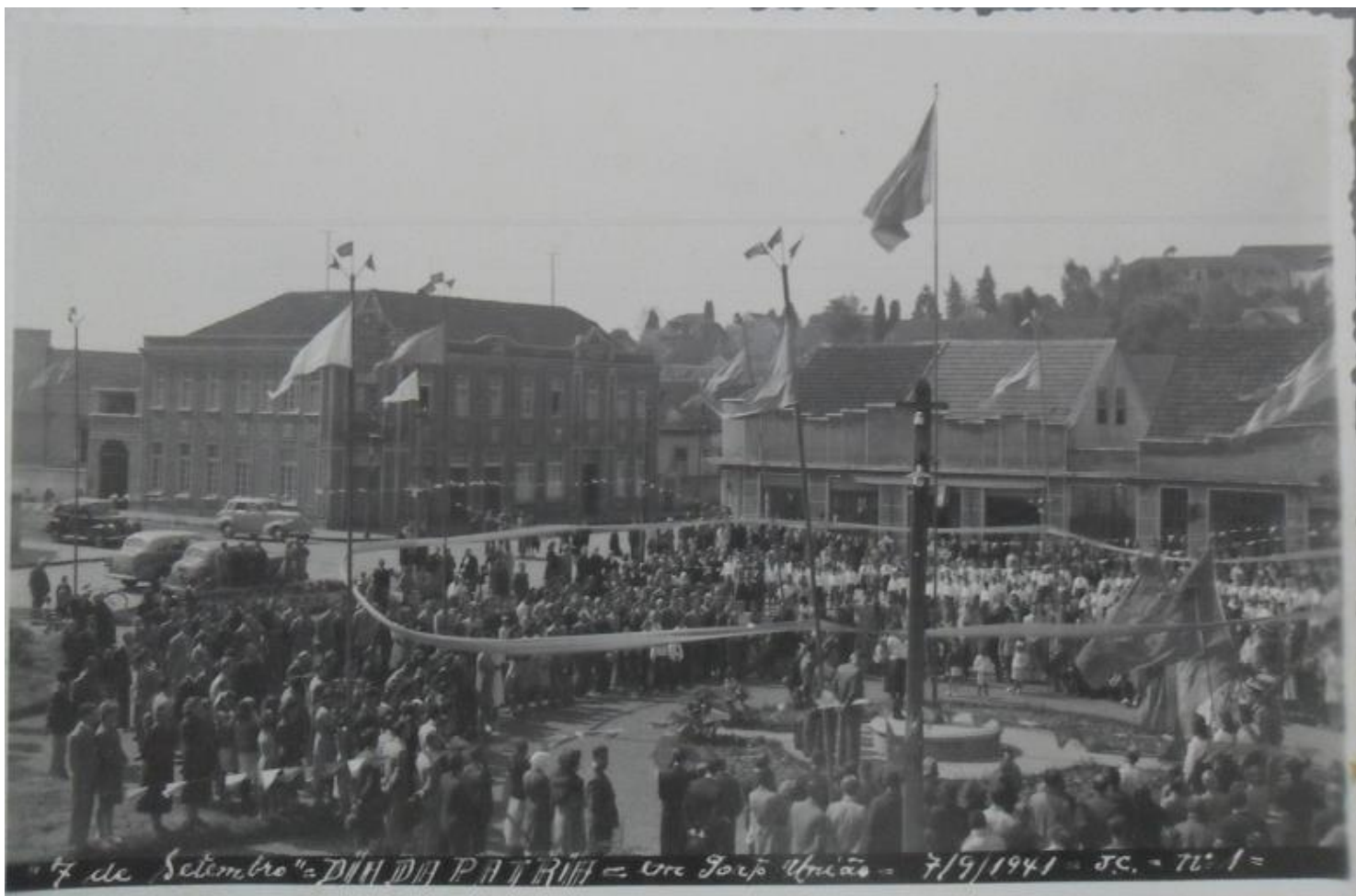

Fonte: Florianópolis: Arquivo Público, 1941.

A Praça Hercílio Luz (até os dias atuais é palco das sessões solenes da semana da pátria na cidade de Porto União, SC) localiza-se na divisa dos Estados de Santa Catarina e do Paraná, junto à Estação Ferroviária de Porto União (SC). Observam-se os prédios que fazem parte do conjunto urbano do local e alguns veículos estacionados junto à praça. Após hasteada, a Bandeira Nacional tremulava ao vento enquanto era "saudada pela gentil senhorita Vinis Pimpão", uma estudante do Curso Normal do Colégio Santos Anjos. Ainda naquele dia, os estudantes e os atletas das escolas das cidades "em ordem de marcha [...] percorreram as ruas de Porto União e União da Vitória” e participaram de várias competições esportivas (O COMÉRCIO, 14/09/1941b, p. 1).

Durante o desfile (Figura 3), uma estudante do Ginásio São José (escola confessional), devidamente uniformizada, com ornamento no cabelo e "ladeada por correta guarda de honra", conduzia a Bandeira Nacional pela avenida que une as cidades vizinhas, simbolizando também a união possível das duas cidades: "foi um dos mais imponentes desfiles já presenciados em nossa terra [...] os estudantes puseram-se em ordem de marcha, sob comando" (O COMÉRCIO, 14/09/1941b, p. 1). A marcha de jovens estudantes e atletas representava o júbilo da Juventude Brasileira nas cidades fronteiriças. 
Figura 3. Dia da Pátria em Porto União (SC) e União da Vitória (PR)

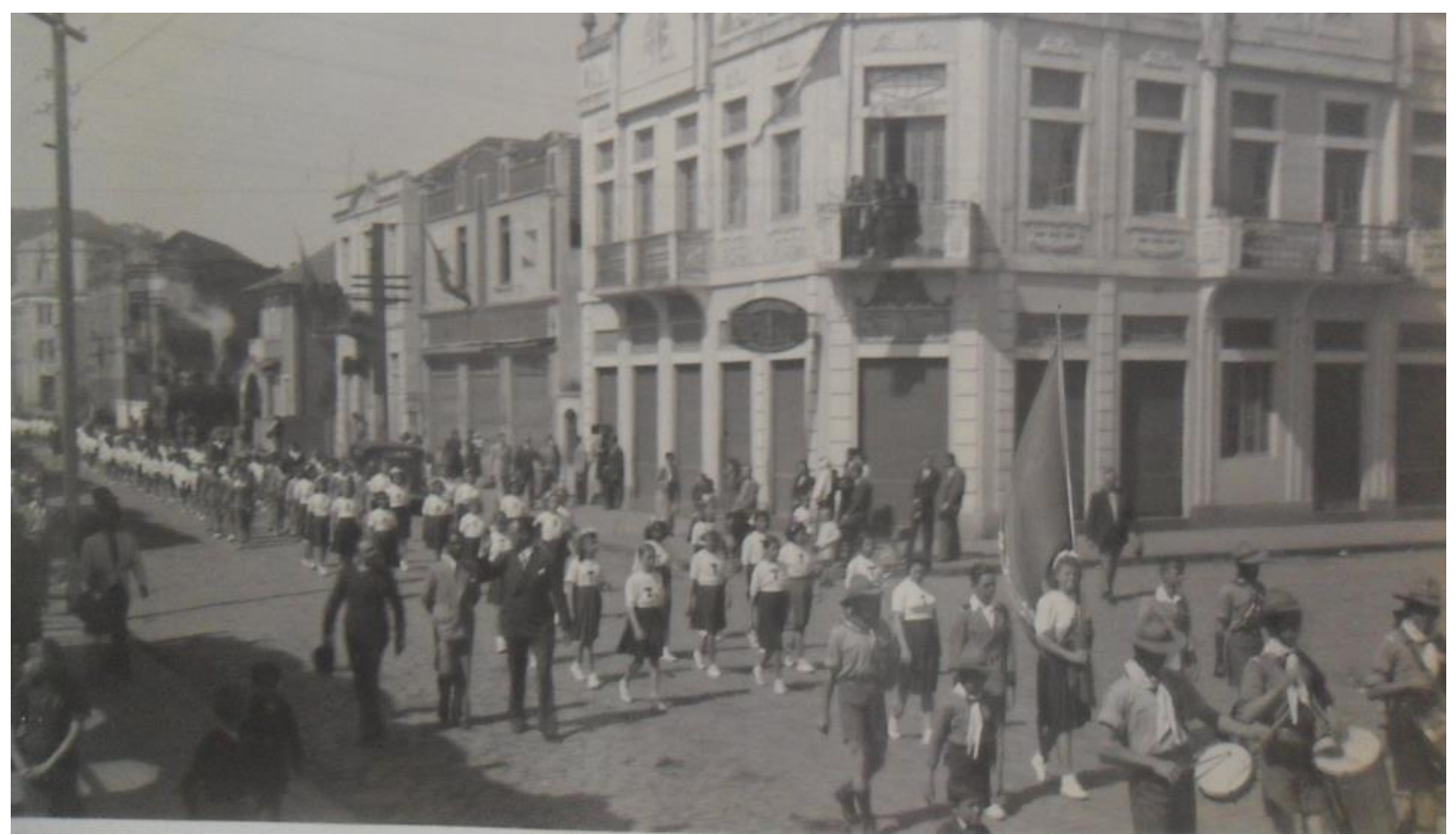

Fonte: Florianópolis: Arquivo Público, 1941.

Para o jornalista, o deslumbrante cortejo era a expressão do mais profundo amor pelo Brasil. Ao término da matéria, o diretor do Grupo Escolar Balduíno Cardoso, de Porto União (SC), professor Gregório Breckenbrok e as professoras, "suas abnegadas auxiliares [que] conduziam, disciplinarmente, os quinhentos e tantos brasileirinhos, cuja educação lhes está confiada" foi também reconhecido (O COMÉRCIO, 14/09/1941b, p. 1). Foram mencionados pelo significativo espaço ocupado na educação das crianças das cidades, onde estudavam mais de 500 crianças.

Um animado "torneio esportivo infantil" foi realizado no mesmo dia, após o desfile, finalizando "as solenidades do 'Dia-da-Pátria', neste ano comemorado com elevado amor ao Brasil” (O COMÉRCIO, 14/09/1941b, p. 1). Entendia-se que a prática esportiva deveria integrar a vida dos trabalhadores, logo era necessário ser estimulada e valorizada desde a infância. Destacamos o papel da imprensa nas representações construídas acerca da ideia de patriotismo, nação, civismo, juventude e educação, com a retransmissão "para o público, as solenidades efetivas na capital da República, e, de lá, irradiadas pelo Departamento de Imprensa e Propaganda, ouvindo-se, aí, a palavra do Presidente Vargas, na 'Hora da Independência"” (O COMÉRCIO, 14/09/1941b, p. 1). A imprensa fazia o elo entre os interesses do governo ditatorial e a população local, reafirmando princípios conservadores/liberais com centralidade da família idealizada, moral civismo, trabalho e êxito individual.

Diante das especificidades da pesquisa, Bertucci, Faria Filho e Oliveira (2010, p. 58) ponderam que a escola é "produtora e produto da sociedade", organizando-se na "confluência de interesses políticos, culturais, econômicos e sociais os mais variados”. Assim, para compreender as ações socioeducacionais é necessário considerar a conjuntura nacional, associada a questões regionais que permitem resultados únicos para a sociedade, como por 
exemplo, cidades de dois estados, separadas por um Acordo de Limites, unirem-se em comemorações em prol de um ideal de formação da pátria e da nação brasileira.

\section{Considerações finais}

Este estudo tinha por objetivo compreender o papel das festividades e desfiles cívicos na formação da juventude nas cidades fronteiriças de União da Vitória (PR) e Porto União (SC), após a publicação do Decreto-Lei no 2072, de 8 de março de 1940 (BRASIL, 1940). A investigação foi realizada com base em documentos históricos e nos leva a concluir que, mesmo em cidades do interior, havia relações entre as práticas socioeducacionais e a ordem política nacionalista de Vargas. A ideia da Juventude Brasileira foi assimilada por representantes da elite local, da igreja católica e de educadores.

A Juventude Brasileira era guiada pela ênfase na educação cívica (incutindo no espírito das crianças e jovens, o sentimento de responsabilidade pela segurança e engrandecimento da pátria), moral (visando à elevação espiritual da personalidade, amor ao trabalho e confiança no próprio esforço) e física (fortalecendo a saúde das crianças e dos jovens, tornando-os resistentes e aptos para esforços continuados, dando ao corpo solidez, agilidade e harmonia). Os interessados na manutenção da ordem vigente se uniram em prol de ações convergentes para a consecução dos objetivos. A imprensa atuou na difusão de representações acerca dos ideais conservadores, enaltecendo a ordem instituída.

Como o discurso é determinado por ideais de grupos sociais a partir de seus interesses, a Juventude Brasileira cumpria sua razão de existir na medida em que seus princípios fossem vividos e suas ações disseminadas para a formação "de operários cultos, de soldados instruídos, de cidadãos conscientes da sua responsabilidade", conforme O Comércio, Porto União (14/09/1941b, p. 1). A lealdade à Pátria era reafirmada pela participação nos desfiles. Contudo, é necessário considerar também a existência de práticas de resistência a essas medidas no interior da própria escola e da sociedade, sejam elas partindo de estudantes, professores, pais de alunos ou sejam de pessoas da comunidade, especialmente os imigrantes.

\section{Referências}

BENCOSTTA, Marcus Levy Albino. Desfiles patrióticos: memória e cultura cívica dos grupos escolares de Curitiba (1903-1971). In: VIDAL, Diana Gonçalves (org.). Grupos Escolares: cultura primaria e escolarização da infância no Brasil (1893-1971). Campinas, São Paulo: Mercado de Letras, 2006. p. 299-322.

BENCOSTTA, Marcus Levi. A História da educação e cultura escolar: representações e imagens das festas escolares. In: VIDAL, Diana Gonçalves; SCHWARTZ, Cleonara Maria (org.) História das culturas escolares no Brasil. Vitória, Espírito Santo: Edufes, 2011. p. 247-268. 
BERTUCCI, Liane Maria; FARIA FILHO, Luciano Mendes de; OLIVEIRA, Marcus Aurelio Taborda de. Edward P. Thompson: história e formação. 1 ed. Belo Horizonte: Editora UFMG, 2010.

BOBBIO, Norberto; MATTEUCCI, Nicola; PASQUINO, Gianfranco. Dicionário de política. Tradução de Carmen C. Varriale et al. Brasília: Editora UnB, 1998.

BORGES, Maria Eliza Linhares. História \& Fotografia. Belo Horizonte: Autêntica, 2003.

BOTO, Carlota. Instrução pública e projeto civilizador: o século XVIII como intérprete da ciência, da infância e da escola. São Paulo: Editora Unesp, 2017.

BRASIL. Decreto-Lei no 2072, de 8 de março de 1940. Dispõe sobre a obrigatoriedade da educação cívica, moral e física da infância e da juventude, fixa as suas bases, e para ministrála organiza uma instituição nacional denominada juventude Brasileira. Rio de Janeiro, 1940. Disponível em: http://www2.camara.leg.br/legin/fed/declei/1940-1949/decreto-lei-2072-8marco-1940-412103-publicacaooriginal-1-pe.html. Acesso em: 15 dez. 2018.

CARVALHO, José Murilo de. A formação das almas: o imaginário da República no Brasil. São Paulo: Companhia das letras, 1990.

CHARTIER, Roger. A história cultural: entre práticas e representações. Rio de Janeiro: Editora Bertrand, 1990.

COSTA, Veronica Albano Viana. Entre imagens e palavras: educação e nacionalismo no Estado Novo (1937-1945). 2009. 190f. (Mestrado em Educação) - Programa de PósGraduação em Conhecimento e Inclusão Social, Universidade Federal de Minas Gerais, Belo Horizonte, 2009.

FARGE, Arlette. O Sabor do Arquivo. Tradução de Fátima Murad. São Paulo: Edusp, 2009.

GALLO, Ivone Cecília D’Avila. O Contestado: o sonho do milênio igualitário. Campinas: Unicamp, 1999.

GASPARI, Leni Trentim. No tempo dos trens nas “Gêmeas do Iguaçu”: uma viagem ao passado. 1 ed. União da Vitória: FAFIUV, 2011.

HOCHE, Aline de Almeida. A hora da juventude: a mobilização dos jovens no Estado Novo (1940-1945). 2015. 178 f. Dissertação (Mestrado em História) - Universidade Estadual do Rio de Janeiro, Rio de Janeiro, 2015.

HOBSBAWM, Eric. Nações e nacionalismo desde 1780: programa, mito e realidade. Tradução de Maria Célia Paoli e Anna Maria Quirino. Rio de Janeiro: Paz e Terra, 1990.

HOBSBAWM, Eric. Sobre história. Tradução de Cid Knipel Moreira. São Paulo:

Companhia das Letras, 1998.

HORTA, José Silvério Baía. O hino, o sermão e a ordem do dia: regime autoritário e a educação no Brasil (1930-1945). 2 ed. Campinas: Autores Associados, 2012. 
IHLENFELD, Renate. A presença da cultura alemã sobre o pensamento pedagógico do Colégio Teuto-brasileiro de Porto União/SC e sua influência sobre o imaginário dos alunos 1930-1938. 2011. Monografia (especialização) - Centro Universitário de União da Vitória, União da Vitória, 2011.

JUCK, Estevam. Palavras do Professor Juck proferidas no Dia da Juventude. O Comércio. Porto União/SC, ano 10, p. 1, 14 set. 1941.

KLEIN, Roseli Bilobran; STENTZLER, Márcia Marlene. Arquivos escolares: uma caixa de surpresas com as especificidades e características de uma instituição educativa. Revista HISTEDBR On-line. Campinas, v. 18, n. 2, p. 420-444, abr./jun. 2018.

LE GOFF, Jacques. História e memória. Tradução de Bernardo Leitão et al. 5. ed. Campinas: Editora da Unicamp, 2003.

LEITE, Eldo Lima et al. Nacionalismo, patriotismo e essencialismo na construção da identidade nacional brasileira. Temas em Psicologia. Ribeirão Preto, v. 26, n. 4, p. 2063 2075, out./dez. 2018.

LOPES, Eliane Marta Teixeira. Prefácio. In: HORTA, José Silvério Baía. O hino, o sermão e a ordem do dia: regime autoritário e a educação no Brasil (1930-1945). 2. ed. Campinas: Autores Associados, 2012.

MACHADO, Paulo Pinheiro. Lideranças do Contestado. Campinas: Ed. Unicamp, 2004.

MÉLO FILHO, Lilian Renata de. O Centro Educativo Operário em Recife durante o Estado Novo (1937-1945): educação e religião no controle dos trabalhadores. 2006. 123 f. Dissertação (Mestrado em Educação). Universidade Federal de Pernambuco, Recife, 2006.

O COMÉRCIO. Comemorações cívicas. Porto União, Santa Catarina, 1941a.

O COMÉRCIO. No 'Dia da Pátria'. Porto União, Santa Catarina, 1941 b.

PAULINO, Carla Viviane. O impulso neoliberal e neoconservador na educação brasileira: a imagem do "professor doutrinador" e o projeto "escola sem partido". Revista Educere et Educare. Cascavel, v. 13, n. 28, p. 1-24, maio/ago. 2018.

SANTOS, Ademir Valdir dos. Educação e fascismo no Brasil: a formação escolar da infância e o Estado Novo (1937-1945). Revista Portuguesa de Educação. Braga, v. 25, n. 1, p. 137$163,2012$.

SAVIANI, Dermeval. Escola e Democracia. 42 ed. Campinas, SP: Autores Associados, 2012.

STENTZLER, Márcia Marlene. Entre questões lindeiras e a superação de fronteiras: a Escola Complementar em Porto União (SC) e União da Vitória (PR), 1928-1938. 2015. 181 f. Tese (Doutorado em Educação) - Programa de Pós-Graduação em Educação da Universidade Federal do Paraná, Curitiba, 2015. 
STENTZLER, Márcia Marlene. Escolas Complementares: um novo modelo de escola para a formação de professores na região do Contestado (1928-1938). Práxis Educativa. Ponta Grossa, v. 13, n. 3, p. 769-786, set./dez. 2018.

TONON, Eloy. Os monges do Contestado: Permanências das predições e rituais no imaginário. 1 ed. Palmas: Kaygangue, 2010. 